\title{
The Role of the Cognitive Variables on Intention to Entrepreneurial Behavior of Engineering Undergraduates in Sri Lanka
}

\author{
W M I Udayanganie (Corresponding author) \\ Graduate School of Management, Management \& Science University \\ No 300, Galle Road, Colombo 3, Sri Lanka \\ E-mail: iresha.meegaawatta@gmail.com \\ Mazuki Jusoh \\ Graduate School of Management, Management \& Science University \\ University Drive, Off Persiaran Olahraga, 40100 Shah Alam, Selangor, Malaysia \\ E-mail: keyjus@yahoo.com
}

\begin{abstract}
Karuthan Chinna
Graduate School of Management, Management \& Science University University Drive, Off Persiaran Olahraga, 40100 Shah Alam, Selangor, Malaysia E-mail: karuthan@gmail.com
\end{abstract}

Received: June 8, 2019

Accepted: June 18, 2019

Published: June 22, 2019

doi:10.5296/jebi.v6i1.14927

URL: http://dx.doi.org/10.5296/jebi.v6i1.14927

\begin{abstract}
The purpose of this research is to assess the role of cognitive variables on intention to entrepreneurial behaviour of engineering undergraduates in engineering undergraduates in Sri Lanka. Entrepreneurship is one of the key drivers of an economy. Individuals with entrepreneurial mind create wealth and majority of jobs in the economy. Entrepreneurship for
\end{abstract}


engineers is not new to the world. Recent changes in the world and engineering present both challenges and opportunities to engineering education. Engineering education is changing to meet these challenges. Instilling an entrepreneurial mindset in undergraduate engineers is essential if we want the bright young talent to innovate and then productize those innovations to better mankind. A study was conducted with the sample of 202 final year undergraduates in engineering faculties in Sri Lanka. Exploratory Factor Analysis, Multiple Regression and Structural Equation Modeling were applied with use of SPSS and AMOS to analyze the relationships of these variables. The results reveal that Entrepreneurial Cognition have significant positive associations with entrepreneurial mindset of engineering undergraduates and there are significant associations between Arrangement, Willingness and Ability with the entrepreneurial Mindset and Entrepreneurial mindset with Intention to entrepreneurial behaviour.

Keywords: Entrepreneurial Cognition, Mindset, Intention to entrepreneurial behaviour, Engineering undergraduates

\section{Introduction}

The entrepreneurial activity and the formation of new businesses on the economic growth of a country and the creation of jobs are recognized worldwide. The study of Ashvini in 2011 found that hundreds of companies throughout the world create products that catch user fancy. This creates an increased demand which ultimately means businesses invest more in technology and thus look for people or train them to acquire new sets of skills. In the end it brings more jobs and more prosperity to the world. Another way how entrepreneurship helps the economy is by innovation and research and development. It was found that $2 / 3$ of all inventions come from entrepreneurs (Fox, 2001). New inventions can improve the economy because they can provide better ways of doing tasks, and can also lead to new businesses that contribute to the economy and conceptualizations were introduced to address the emerging need to develop innovativeness and creativity attitudes in future engineering professional. The entrepreneur has been defined as 'an innovator or developer who recognizes and seizes opportunities, and converts these opportunities into workable and/or marketable ideas' (Kuratko, D., 1995). With this definition, engineering educators and policy makers agree that twenty-first century engineers need to be able to address societal problems through innovations and enhanced functionality; work in multicultural environments; understand the business context of engineering; work in interdisciplinary teams; and adapt to changing conditions (Kauffman Foundation, 2008, National Academy of Engineering, 2005, National Science Board, 2007). There is no denying the fact that the current training mission for engineers in higher education is being continually reformed and developed. With the development of economic globalization, the contents of engineering education have been extended from the engineering sciences, technology, and management to the natural sciences, social sciences, etc. (Shu-yu, G. \& Xiao-dong, Z., 2011). 
Developing the entrepreneurial intention of engineering students is important for the emergence of high-tech businesses (Roberts, E.B., 1991, Shane, S., 2000). Entrepreneurial engineers not only need a rigorous engineering education, but also need to understand the elements of entrepreneurship. Young entrepreneurial engineers must know how to take advantage of the knowledge in our market place, and how to create new value (Wang, Y., \& Verzat, C., 2011). The development of entrepreneurial engineering talent's ability has played an important role in the modern higher engineering educational reform, in building an innovative country, and enhancing overall national strength and competitiveness.

\subsection{Background of the Study}

The 21 st century is characterized by the shift from the managerial economy to the entrepreneurial economy (Audretsch \& Turik, 2001) in which the economic growth depends on both high technology and innovative entrepreneurship.

Governments and local communities across the world have recognized that key to building prosperity and stimulate regional growth is fostering entrepreneurship among their people especially youth.

Sri Lanka introduced the open economic policy in the year 1977 before many other countries in Asia to align country's economy to world economic trends and to earn a higher economic growth whilst using innovations and new product developments along with development of new services.

Before 1977 Sri Lanka practiced an inward-looking economic policy which promoted many indigenous businesses since the government promoted local businesses by giving many incentives and subsidies to them. However, after 1977 due to open economic policy, indigenous businesses had to compete with foreign products, processes, technology, services, innovations and businesses. Hence, doing businesses in this context was very complex as well as more dynamic than in the past.

Therefore, currently Sri Lanka facing such a situation of complexity and a dynamic environment. In the year 1977 the private sector was made the "engine of growth" and it was given the authority and precedence to drive the country's economic growth. This was a transfer from public entrepreneurship to private entrepreneurship in Sri Lanka to develop the country. Therefore, the country must try to see new drives to develop the country through private entrepreneurship not only because it is the "engine of growth", but also to align the country's development process to world inclinations.

Entrepreneurs are reflected as major contributors to a country's economic and development in many countries worldwide. In early days it was assumed that entrepreneurs are borne. But now the world has accepted that entrepreneurs can be taught and there are factors which can influence a person's entrepreneurial thinking. It is commonly accepted that educational system in universities is responsible to provide an academic environment as to produce more 
business founders. Thus, in today's scenario, entrepreneurship and other business related subject such as Innovation Management and Technology Entrepreneurship is being thought to an engineering students. Entrepreneurship is getting prominence in schools, colleges and universities across the world. Today's globalized world of advanced technology and competition in the business world has further escalated the importance of entrepreneurship.

But in Sri Lanka it has a huge vacuum for innovation and entrepreneurs. Since Sri Lanka is almost in the developing stage, it has great potential to develop further with these engineering entrepreneurs. Therefore, the engineering graduates must have an innovative mindset, with practical knowledge in order to suit the requirements of the modern world. Technical understanding is essential to engineering. But engineers find success and personal fulfillment when they couple these skills with a mindset to create extraordinary value for others. The key is an entrepreneurial mindset. And it can be applied to any subject, including engineering.

The cognitive approach to the study of entrepreneurs emerged as an alternative to the trait orientation because although the latter has produced important results, many of these have been clearly contradictory, generating the displacement of researchers to other personal aspects of the individual (Baron \& Markman, 1999; Boucknooghe, Van den Broeck, Cools, \& Vanderheyden, 2005; Vecchio, 2003).

\subsection{Aim and Objectives of the Study}

Aim of the study was to investigate the role of the cognitive variables on intention to entrepreneurial behavior of engineering undergraduates in Sri Lanka. The specific objectives of this study were:

1) To identify the association between entrepreneurial cognition and the entrepreneurial mindset.

2) To identify the association between entrepreneurial mindset and the intention to entrepreneurial behaviour of engineering undergraduates.

3) To identify if entrepreneurial mindset mediates amongst the entrepreneurial cognition and intention to entrepreneurial behaviour.

\section{Literature Review}

The focused areas of Literature search were on the Intention to Entrepreneurial Behaviour and the impact of Entrepreneurial Cognition and the Mindset on it.

\subsection{Entrepreneurs' Behavioural Intention}

Since entrepreneurship occurs over time (Gartner et al., 1994), entrepreneurial intentions can be viewed as the first step in an evolving long-term process of organizational founding. It is also important to understand an individual's entrepreneurial intentions because it is a state of mind that directs the individual's attention, experience and action toward the goal of founding a business (Bird, 1988). Entrepreneurial intentions represent an individual's 
commitment to start a new business (Krueger, 1993). In addition, intentions towards a behavior have routinely been proven to be the best single predictor of that behavior (Fishbein \& Ajzen, 1975). Absent intention, action is unlikely. Hence, entrepreneurial intentions are crucial to understanding the overall process of entrepreneurship because entrepreneurial intentions serve as the key initial conduit for subsequent actions and events that affects the characteristics of the new organizations (Bird, 1988; 1992; Boyd \& Vozikis, 1994; Crant, 1996; Jenkins \& Johnson, 1997; Katz \& Gartner, 1988; Krueger, 1993; 2000; Krueger \& Carsrud, 1993). Therefore, a model that focuses on entrepreneurial intentions offers an important framework to pursue a better understanding of the entrepreneurial processes (Krueger, 1993; 2000). Intentions play a key role in explaining human behaviors (Tubbs \& Ekegerg, 1991). Many social behaviors, such as creating a new business, are volitionally controlled and these behaviors have been found to be best predicted by intentions (Ajzen, 1991; 2005; Bagozzi et al., 1989). Similar to entrepreneurship, different understandings of entrepreneurial intentions have been observed. Katz and Gartner (1988) defined entrepreneurial intention in terms of looking for information and other resources to start up. Bird $(1988 ; 1992)$ defined that intention as a state of mind that emphasizes personal attention and experience to accomplish new venture creation. Focusing on cognitive representation, Tubbs and Ekeberg (1991) stated that an intention is a representation of actions planned to perform an entrepreneurial behavior. Other researchers, for example, Reynolds and Miller (1992) understood entrepreneurial intention as the personal commitment of the potential entrepreneur to start up. In the same way, Krueger (1993) and Krueger et al. (1995) argued that entrepreneurial intention is the commitment to performing entrepreneurial behavior.

\subsection{Entrepreneurial Cognition}

The cognitive approach uses the cognitive aspects of entrepreneurs to study and even to explain their behavior, which is related to the identification of opportunities for the creation of businesses and business growth. In fact, the term cognitive style is used to characterize certain ways of processing information related to entrepreneurial behavior. Two main lines can be differentiated within the cognitive literature: the study of cognitive structures and the study of cognitive processes. Some studies have attempted to identify the knowledge structures that entrepreneurs use to make assessments, judgments or decisions, in evaluating opportunities, and in the creation and growth of businesses (Boucknooghe et al., 2005; Busenitz \& Barney, 1997; Gaglio \& Katz, 2001; Mitchell, Smith, Seawright, \& Morse, 2000; Sánchez, 2009). Other types of research are based on the idea that whatever the individual thinks, says or does is influenced by the cognitive processes through which individuals acquire, use and process information (Baron \& Markman, 1999; Krueguer \& Evans, 2004; Neisser, 1967). This perspective suggests that entrepreneurs think and process information differently from non-entrepreneurs and such differences may help to distinguish people who 
create or aim to establish businesses (entrepreneurs) from people who do not create and will not create companies (non-entrepreneurs). Thus, some authors have coined the term "cognitive style" to characterize certain ways of processing information related to entrepreneurial behavior (Baron, 2004; Boucknooghe et al., 2005; Van den Broeck, Vanderheyden, \& Cools, 2003). Cognitive psychology is not only an aid to understanding individuals and their behavior, considering their mental processes when they interact with other people, but also addresses the environment in which these mental processes and interactions take place (Mitchell, Busenitz, Lant, McDougall, Morse, \& Smith, 2002). The idea that cognitions are structured in the minds of individuals and that these knowledge structures act as 'scripts' in that they are the antecedents of decision-making is long established (Read, 1987, p. 289). Cognitions are all the processes by which sensory input is transformed, reduced, elaborated, stored, recovered and used (Neisser, 1967, p. 4). A definition that builds on previous research defines entrepreneurial cognitions as the "knowledge structures that people use to make assessments, judgments, or decisions involving opportunity evaluation, venture creation, and growth" (Mitchell, Busenitz et al., 2002, p. 97). Individuals in decision-making situations typically draw upon scripts or knowledge structures to make decisions to act. Some of these scripts are well developed (expert scripts) while others (novice scripts) are not as fully developed, resulting in information processing-based thinking errors. Specifically, entrepreneurial decisions are the result of motivation and cognitions, the latter including intellect, ability and skills. Cognition Theory has been developed to the point where three types of cognitive scripts (arrangements, ability and willingness) have been found to be central to expert performance (Mitchell et al., 2000; Smith, Mitchell, \& Mitchell, 2009).

a. Arrangement scripts are the contacts, relationships, resources and assets necessary to form a new venture. These scripts are the knowledge structures that individuals have about the use of specific arrangements that support their performance and expert-level mastery in a given domain. Typically, individuals making a venture creation decision use appropriate arrangement scripts concerning idea protection, venture networking, accessing resources and venture-specific skills.

b. Willingness cognitions are the mental maps that support commitment to venturing and receptivity to the idea of starting a venture. They include actionable thoughts about opportunity seeking (Krueger \& Brazeal, 1994, p. 92), commitment tolerance (Hisrich, 2000, p. 80) and venture opportunity pursuit (McClelland, 1961). Willingness scripts that fo-cus on opportunity seeking are concerned with openness, orientation and drive toward seeking out new situations and possibilities and trying new things. According to Mitchell et al. (2000, p. 988), entrepreneurs are expected to have more highly developed scripts relating to opportunity seeking, commitment tolerance and opportunity pursuit than non-entrepreneurs. 
Willingness scripts also permit entrepreneurs to experience less risk than non-entrepreneurs because these scripts reduce uncertainty (Krueger, 1993, p. 6). Without willingness scripts, doing/enactment is precluded because prospective venturers will not have the motivation or commitment to make venture creation decisions (Krueger, 1993, p. 7).

c. Ability cognitions consist of the knowledge structures or scripts that individuals have to support the capabilities, skills, knowledge, norms and attitudes required to create a venture. At least three scripts relating to ability appear in the entrepreneurship literature: venture diagnostic scripts, situational knowledge scripts and ability-opportunity fit scripts. Venture diagnostic scripts concern the ability to assess the condition and potential of ventures and to understand the system-atic elements involved in their creation (Krueger, Reilly \& Carsrud, 2000, p. 412). Situational knowledge scripts involve the ability to draw on lessons learned in a variety of ventures and apply those lessons to a specific situation. Finally, ability-opportunity-fit scripts concern the ability to see ways in which customer and venture value can be created in new combinations of people, materials or products. Ability scripts include the capability to assess conditions and potential new ventures, to draw on and apply lessons learned in a variety of ventures and to both see the need for and carry out creation of value by matching opportunity and capability, hence a gain in self efficacy in making the venture creation decision.

\subsection{Entrepreneurial Mindset}

A mindset is defined by Merriam-Webster as a "mental attitude or inclination." As further elaborated upon by Thum (2012). Carol Dweck (2006) acknowledges that a mindset can be fixed or growth oriented. From an academic standpoint, the mindset concept comes out of the cognitive psychology and organization theory fields

The environment for engineering will continue to undergo significant transformations, driven by global competition in high-tech markets, the outsourcing of production and services, the explosion in the information technology sector, the cross-fertilization among traditional engineering disciplines, and the complicated issues associated with environmental protection and sustainable development (Creed et al., 2002). . It is becoming more commonly understood and accepted that engineers need business, social, and interpersonal skills to operate effectively in the organizational environments in which they work (Gokhale 1995). The development of such entrepreneurial mindset in engineers and scientists requires a significant change of university processes that have to integrate educational and research systems, in the final perspective to generate and experiment sustainable innovation processes and practices.

\section{Conceptual Framework}

Considering the most important variables for Entrepreneurial Cognition leading to develop Entrepreneurial Mindset for Engineering undergraduates is been captured to develop the 
conceptual framework and Entrepreneurial Mindset as a mediator in the path of Entrepreneurial cognitive variables to leading intention to entrepreneurial behaviour.

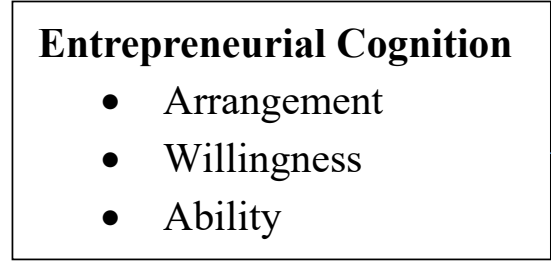

- Ability

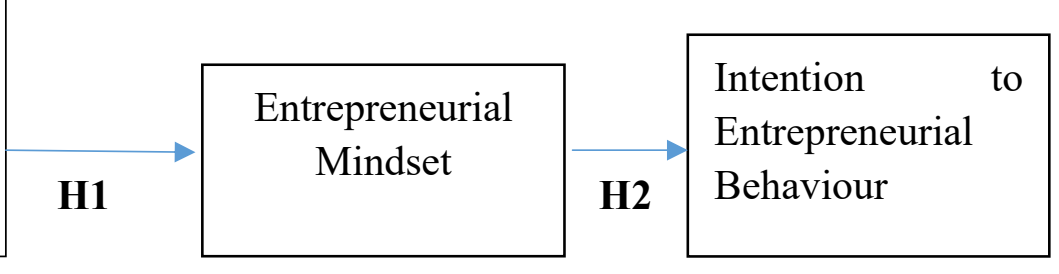

H3

\subsection{Research Hypothesis}

Based on the conceptual framework listed below are the hypothesis proposed

H1: There is an association between entrepreneurial cognition and the entrepreneurial mindset of engineering undergraduates

H1a: There is an association between Arrangement and entrepreneurial Mindset

H1b: There is an association between Willingness and entrepreneurial Mindset

H1c: There is an association between Ability and an entrepreneurial Mindset

H2: There is an association between Entrepreneurial Mindset and the intention to entrepreneurial behaviour of engineering undergraduates.

H3: The mindset mediates the relationship between cognitive aspects and bahavioural intention on entrepreneurship.

\section{Method}

Final year undergraduates of the selected three engineering faculties in Sri Lanka selected as a study population. The researcher selected a random sample of 300 final year undergraduates who are aware about the entrepreneurship-related modules from the three engineering faculties. Out of the 300 students, 202 students responded to the survey questionnaire which made up a response rate of the study $67 \%$. A questionnaire was developed, tested and distributed among the undergraduates and quantitative methodology was used for data collection and analysis. In the Analysis process by using questionnaires, a few procedures can be done such as checking the data for accuracy. This research adopts a quantitative research method as the main design, which is most appropriate for this study. As Saunders et al. (2015) suggested not only the quantitative techniques belong to the survey strategy but as well as qualitative techniques are also applicable in survey methods for the collection of data. Besides that, the questions were being coded to enable for analysis using Statistical Packages for the Social Science (SPSS). First, the descriptive statistics of the study explained the primary data of the analysis and then the regression analysis was carried out to analyze the relationships and then to determine the conceptual model of the study. Exploratory Factor Analysis, Multiple Regression and Structural Equation Modeling were applied with use of SPSS and AMOS to analyze the relationships of these variables. The bootstrapping method 
was performed to measure the significant of the mediator impact.

The scales used to measure expertise in arrangement, willingness, and ability scripts were adopted from Mitchell et al. (2000, 2002). These authors developed 27 items to measure expertise in entrepreneurial scripts indirectly, following an accepted script-scenario construction model proposed by Read (1987). In this approach, the existence and degree of mastery of scripts is inferred based on selection by respondents from paired response choices; one represents expertise and the other is a distracter cue. When solving problems within a specific domain, experts are able to select the response consistent with their expert scripts whereas non-experts are more likely to choose the socially desirable distracter cue (Crowne \& Marlowe, 1964). Each scripts scale is comprised of 5 items. All items ask the participants for a choice between an expert script (coded as " 1 ”) and a distracter cue (coded as “ 0 ").

\section{Results}

The standardized regression weights were used since they allow to compare directly the relative effect of each independent variable on the dependent variable (Crompton, H., Burke, D., Gregory, K. H., \& Gräbe, C.2016). The significance is based on the critical ratio (CR) of the regression estimate (Hair, 1998).

The Table 1 presents the standardized regression estimates and the direct association between the study constructs.

Table 1. Results of the hypothesis testing

\begin{tabular}{lllll}
\hline Path & Estimate & S.E. & C.R. & P \\
\hline Mind <--- Ar & .077 & .029 & 2.648 & .008 \\
Mind <--- Ab & 2.772 & 1.112 & 2.494 & .013 \\
Mind <--- wil & 2.339 & .785 & 2.981 & .003 \\
Ent.int. <--- Mind & .979 & .181 & 5.418 & $* * *$ \\
\hline
\end{tabular}

Thus, Hypothesis H1a, H1b, H1c and H2 were accepted.

Table 2. Mediation relationship

\begin{tabular}{|c|c|c|c|c|}
\hline Mind set & Arrangement & Ability & Willingness & \\
\hline $\begin{array}{l}\text { Intention to } \\
\text { entrepreneurship }\end{array}$ & -.087 & -9.757 & .642 & $\begin{array}{l}\text { Lower } \quad 95 \% \\
\text { confidence limit }\end{array}$ \\
\hline $\begin{array}{l}\text { Intention to } \\
\text { entrepreneurship }\end{array}$ & -.029 & -.755 & 5.852 & $\begin{array}{l}\text { Upper } \quad 95 \% \\
\text { confidence limit }\end{array}$ \\
\hline $\begin{array}{l}\text { Intention to } \\
\text { entrepreneurship }\end{array}$ & .002 & .009 & .004 & P-Value \\
\hline
\end{tabular}


Based on the results all hypothesis was revealed to be significant.

\section{Discussion}

The purpose of this study was to analyse the role of the variables of entrepreneurial cognition on intention to entrepreneurial behaviour of engineering undergraduates. Research on entrepreneurial scripts refers to the study of how entrepreneurs use simplified mental models to link previously unconnected information that will help them to identify or invent new products or services and the necessary resources to start up and cultivate a business (Mitchell et al., 2002). The results reveal that Entrepreneurial Cognition have significant positive associations with entrepreneurial mindset of engineering undergraduates and there are significant associations between Arrangement, Willingness and Ability with the entrepreneurial Mindset and Entrepreneurial mindset with Intention to entrepreneurial behaviour. So $\mathrm{H} 1$ and $\mathrm{H} 2$ are supported and the results reveal that the path from Arrangement, Willingness and Ability to Entrepreneurial intention was significant with Entrepreneurial Mindset mediating the relationship. So, H3 also supported.

\section{Recommendations}

In Sri Lankan context entrepreneurial intention of undergraduates has been assessed using may other factors other than the entrepreneurial cognition. Entrepreneurial mindset also provides a different view for entrepreneurial intention for the Sri Lankan context specially for the engineering undergraduates. The study will provide a contribution to the literature in the Sri Lankan context. Based on the study results the Cognitive variables arrangement, willingness and ability were positively impact on entrepreneurial intention of engineering undergraduates. Entrepreneurial mindset also provides a different view for entrepreneurial intention for the Sri Lankan context specially for the engineering undergraduates. The study will provide a contribution to the literature in the Sri Lankan context.

.This study helps academics as well as higher education management to obtain a better understanding of importance of the Entrepreneurial Engineers for the country. This research is significant because it offers insight into industry practitioners. The current study closes the gap in understanding the factors which can impact on the entrepreneurial behaviour of engineers and identifying the importance of entrepreneurial mindset for the decision to be entrepreneur in future. Motivate students in entrepreneurship through start-up exhibitions of successful entrepreneurs in the world of engineering. These role models represent a way of showing students an example of the validity of their project, so that they can envisage it realistically and believe that it can be carried out.

\section{Conclusion}

Based on the findings of the study have come to the conclusion that the study given a special attention on the relationship of entrepreneurial cognition and entrepreneurial mindset on intention to entrepreneurial behaviour. There is a very strong positive relationship among entrepreneurial mindset and intention to entrepreneurial behaviour . and there is a strong relationship with the entrepreneurial cognition factors of arrangement, willingness and ability on intention to entrepreneurial behaviour. Finally, this study offers valuable guidelines and 
insight for those academics, practitioners and government officials who may want to review the effectiveness of current systems of the country and make changes in order to foster the entrepreneurial mindset in individuals. This is particularly important in the context of a developing country such as Sri Lanka seeking to create an entrepreneurial culture for further socio-economic growth and development.

\section{References}

Ajzen, I. (1991). The theory of planned behavior. Organizational Behavior and Human Decision Processes, 50(2), 179-211.

Baron, R. A., \& Markman, G. D. (1999). Cognitive mechanisms: Potential differences between entrepreneurs and non-entrepreneurs. In P. D. Reynolds, W. D. Bygrave, et al. (Eds.), Frontiers of entrepreneurship research. Wellesley, MA: Babson College.

Bird, B. (1988). Implementing entrepreneurial ideas: The case of intentions. Academy of Management Review, 13(3), 442-454.

Creed, C. J., Suuberg, E. M., \& Crawford, G. P. (2002). Engineering entrepreneurship: An example of a paradigm shift in engineering education. Journal of Engineering Education 91(2), 185-195.

Crompton, H., Burke, D., Gregory, K. H., \& Gräbe, C. (2016). The Use of Mobile Learning in Science: A Systematic Review. Journal of Science Education and Technology, 25(2), 149-160. Retrieved May 27, 2019 from https://www.learntechlib.org/p/176198/

Crowne, D. P., \& Marlowe, D. (1964). The Approval Motive. New York: John Wiley \& Sons.

Fishbein, M., \& Ajzen, I. (1975). Belief, attitude, intention and behavior: an introduction to Theory and Research. Reading, MA: Addison-Wesley.

Fox, M. J. (2001). Entrepreneurs Add Up to Big Business. Retrieved at http://sbdc.osu.edu

Gokhale, A. A. (1995). Collaborative Learning Enhances Critical Thinking," Journal of Technology Education, 7(1), 22-30.

Hair Jr., J. F. et al. (1998). Multivariate Data Analysis with Readings. Englewood Cliffs, NJ: Prentice-Hall.

Hisrich, R. D. (2000). Entrepreneurial dimensions: The relationship of individual, venture, and environmental factors to success. Entrepreneurship Theory and Practice.

K. S. Ashvini, (2011). Entrepreneurship Benefits Economy More than Just Generating Jobs. Retrieved at http://aks-blog.com

Krueger, N. F. (1993). The impact of prior entrepreneurial exposure on perceptions of new venture feasibility and desirability. Entrepreneurship: Theory \& Practice, 18(1), 5-21.

Krueger, N. F., Reilly, M. D., \& Carsrud, A. L. (2000). Competing models of entrepreneurial intentions. Journal of Business Venturing, 15(5/6), 411-432. 


\section{Macrothink}

Journal of Entrepreneurship and Business Innovation

ISSN 2332-8851 2019, Vol. 6, No. 1

Kuratko, D. (1995). Entrepreneurship in international encyclo-pedia of business and management. London, UK: International Thomson Press.

McClelland, D. C. (1961). The achieving society. New York: Free Press.

Mitchell, R. K., Smith, J. B., Morse, E. A., Seawright, K. W., Peredo, A. M., \& McKenzie, B. (2002). Are entrepreneurial cognitions universal? Assessing entrepreneurial cognitions across cultures. Entrepreneurship Theory \& Practice, 26(4), 9-32.

Mitchell, R. K., Busenitz, L., Lant, T., Mc Dougall, P. P., Morse, E. A., \& Smith, J. B. (2002). Toward a theory of entrepreneurial cognition: Rethinking the people side of entrepreneurship research. Entrepreneurship Theory and Practice, 93-104.

Neisser, U. (1967). Cognitive psychology. Prentice NJ -Hall Englewood Cliffs, New York.

Read, S. J. (1987). Constructing causal scenarios: A knowledge structure approach to causal reasoning. Journal of Personality \& Social Psychology, 52(2), 288-302.

Reynolds, P. D., \& Miller, B. (1992). New firm gestation: conception, birth and and implications for research.

Roberts, E. B. (1991). Entrepreneurs in High Technology: Lessons from MIT and Beyond. Oxford University Press, Oxford.

Shu-yu, G., \& Xiao-dong, Z. (2011). The Exploration for the Development Modles of Engineering Entrepreneurship. International Conference on Management and Service Science (MASS).

Tubbs, M. E., \& Ekeberg, S. E. (1991). The role of intentions in work motivation: Implications for goal-setting theory and research. Academy of Management Review, 16, 180-199.

Tubbs, M. E., \& Ekeberg, S. E. (1991). The role of intentions in work motivation.

Wang, Y., \& Verzat, C. (2011). Generalist or specific studies for engineering entrepreneurs? Comparison of French engineering students' trajectories in two different curricula. Journal of Small Business and Enterprise Development, 18(2), 366-383. https://doi.org/10.1108/14626001111127124

\section{Copyright Disclaimer}

Copyright for this article is retained by the author (s), with first publication rights granted to the journal.

This is an open-access article distributed under the terms and conditions of the Creative Commons Attribution license (http://creativecommons.org/licenses/by/3.0/). 